\title{
Aquatic Macrophytes in Southern Amazonia, Brazil: Richness, Endemism, and Comparative Floristics
}

\section{Milton Omar Cordova Neyra ( $\sim$ cordova.neyra@gmail.com )}

Universidade de Brasilia Instituto de Ciências Biológicas: Universidade de Brasilia Instituto de Ciencias Biologicas https://orcid.org/0000-

0001-6973-3171

Josiane Fernandes Keffer

Universidade Federal do Paraná: Universidade Federal do Parana

Dienefe Rafaela Giacoppini

MRS Estudos Ambientais

Vali Joana Pott

Universidade Federal de Mato Grosso do Sul

Arnildo Pott

Universidade Federal de Mato Grosso do Sul

Cássia Beatriz Rodrigues Munhoz

Universidade de Brasilia Instituto de Ciências Biológicas: Universidade de Brasilia Instituto de Ciencias Biologicas

\section{Research Article}

Keywords: Aquatic plants, Endemic species, Floristic similarity, Phytogeographic domains, Amazonian wetlands, Cluster Analysis

Posted Date: June 8th, 2021

DOI: https://doi.org/10.21203/rs.3.rs-551537/v1

License: (1) This work is licensed under a Creative Commons Attribution 4.0 International License. Read Full License 


\section{Abstract}

Southern Amazonia potentially harbors a wide diversity of aquatic macrophyte species because of its diverse wetland habitats and location in the Amazon-Cerrado transition zone, the two largest biogeographic domains in South America. We inventoried the taxonomic diversity of aquatic macrophytes in the region, including endemism, habitats, species life forms, and floristic comparisons with other Brazilian regions. We found a high number of species of aquatic macrophytes for the southern Amazon region, comparable to extensive inventories in larger areas in southern, northeastern, and northern regions of Brazil. We recorded 688 species of aquatic macrophytes in 299 genera and 95 families, of which 66 species are new records, 89 endemic, and 5 exclusive to Brazilian Amazonia. We present new records of aquatic macrophyte species, together with their degree of endemism and occurrence restricted to the region. The macrophyte species list of southern Amazonia showed $60 \%$ similarity to inventories in the Xingu basin and in northern Brazil. This high diversity of aquatic macrophytes in the Southern Amazonia, with endemic species and others with restricted ranges, emphasizes the importance of conserving wetlands and vegetation types where they grow in the region.

\section{Introduction}

Aquatic macrophytes grow actively while permanently or periodically submerged, floating, or emerging from the water surface (Chambers et al. 2008) and colonize most aquatic ecosystems to different degrees. The composition, richness, and cover of aquatic macrophytes may be determined by biotic factors such as climate, isolation, diversity of habitats, nutrients, and hydroperiod (Sousa et al. 2011; Schneider et al. 2019; Yang et al. 2020). The richness of aquatic macrophytes depends mainly on the size of a wetland, although their composition may not follow this pattern (Maltchik et al. 2007). Neotropical aquatic environments, with their generally high temperatures, water-level fluctuations, and wide variety of habitats harbor the highest richness and endemism of aquatic macrophytes (Murphy et al. 2003; Fortney et al. 2004; Murphy et al. 2019).

The Amazon Forest, the largest freshwater reserve in the world, supports one of the highest known levels of biological diversity, including over 50,000 terrestrial vascular plant species (Hubbell et al. 2009). The Amazon basin, situated between the Guianas Plateau to the north, the Central Plateau to the south, the Andes Mountains to the west, and the Atlantic Ocean to the east, drains, parts of eight South American countries in addition to Brazil (Hess et al. 2003). This phytogeographic domain covers an area of 6,500,000 km², with $60 \%$ or circa 4.2 million $\mathrm{km}^{2}$ in Brazil, representing $49 \%$ of the country (IBGE 2010). Southern Amazonia extends widely ( $6000 \mathrm{~km})$, between latitudes $11^{\circ} \mathrm{S}$ and $14^{\circ} \mathrm{S}$, and is an area of transition between the Amazon Rainforest and the Cerrado (Brazilian savanna). This ecotone region contains a diversity of habitats and vegetation types, from dense deciduous or evergreen forests to savanna formations (Marimon et al. 2006; Torello-Raventos et al. 2013). Within this environmental complexity, the Cerrado-Amazonia transition zone is rich in typical Amazonian tree species, also shared with the Atlantic Forest and the Cerrado (Marimon et al. 2006; Oliveira-Filho et al. 2017). The woody flora of this transitional region is well known, but the aquatic macrophyte flora is not.

Because of the heavy deforestation pressure for agricultural, timber, and hydroelectric development, this ecotonal region is known as the "Amazon deforestation arc". Deforestation may destroy immense genetic stocks that are little known or documented in herbaria or conserved in germplasm banks. Such genetic erosion can result in loss of valuable information, including information useful in areas such as agriculture, medicine, and industry (Fearnside 2019). Southern Amazonia may potentially harbor an enormous biodiversity of aquatic macrophytes because of its environmental heterogeneity (Murphy et al. 2019). The diverse wetland habitats include permanently or seasonally flooded areas such as streams, rivers, lakes, floodplains, marshes, and swamps, in addition to the reservoirs of several large hydroelectric power plants (Junk et al. 2020). The present study produced a checklist of aquatic macrophytes in southern Amazonia, in particular with information on new records, endemism, habitats, and life forms of the species, besides assessing the floristic similarity of the region to other areas within and outside the Amazon domain

\section{Methods}

\section{Study area}

The state of Mato Grosso in central-western Brazil contains parts of three phytogeographic domains (Amazon, Cerrado, and Pantanal) and a diverse flora with high socio-economic and environmental potential. Vegetation types in the southern Amazon part of northern Mato Grosso include Transitional Forest, Evergreen Seasonal Forest, and Seasonal Forest of the southern Amazon border (Ivanauskas et al. 2004 ; Kunz et al. 2008). This part of southern Amazonia is an area of ecological tension (Veloso et al. 1991). The flux of biodiversity in the Cerrado-Amazonia transition and the complex mosaic of vegetation landscapes make it difficult to delimit the phytogeographic domains, especially in the transition zone (Marimon et al. 2006; Morandi et al. 2016a). The Amazon Forest covers approximately 500,000 $\mathrm{km}^{2}$ in Mato Grosso, with areas of dense forest containing trees that can reach $50 \mathrm{~m}$ in height. The forest is cut through by large rivers and is protected in some preservation areas such as the Cristalino State Park, Rio Ronuro Ecological Station, and Xingu State Park. In the northern region, the Teles Pires and Juruena rivers join to form the large Tapajós River, and together with the Xingu River have a highly diverse flora along their banks (Fig. 1). 


\section{Collection of data}

\section{Survey of aquatic macrophyte species recorded in databases}

To develop the species list for the part of southern Amazonia in mid-northern Mato Grosso, we included georeferenced records of herbaria in the region that are available in the specieslink (https://splink.cria.org.br) and Global Biodiversity Information system (GBIF - www.GBIF.org) databases. We checked all records individually and we added geographic coordinates of records with detailed information on the site location. Our selection of aquatic species followed the Repository of Aquatic Plants of Brazil (https://sites.icb.ufmg.br/plantasaquaticasbrasil) and the Brazilian Flora database (http://floradobrasil.jbrj.gov.br/), using the search filters "State: Mato Grosso", "Phytogeographic domain: Amazonia”, "Substrate: Aquatic" and "Formation: Aquatic Vegetation". Based on reports from the state (Pott and Pott 1997) and the Amazon domain (Costa et al. 2016; Moura-Júnior et al. 2015), we included other species as aquatic macrophytes

\section{Field collections}

We also incorporated species collected by the authors during five years of field research (2015-2020) in the Tapajós (Teles Pires, Cristalino, Juruena) and Xingu (Xingu and Ronuro) sub-basins of the Amazon River, at different times and hydrological periods (drought, rising water, flood, and drawdown). Fertile specimens were recorded using random sampling, following the procedure described by Filgueiras et al. (1994). We identified the species by consulting literature, taxonomists, and herbarium collections. The specimens are kept in the Centro-Norte-MatoGrossense Herbarium (CNMT) of the Acervo Biológico da Amazônia Meridional (ABAM) at the Universidade Federal de Mato Grosso (Sinop Campus), and establish several unique records for the state of Mato Grosso. We used the concept of aquatic macrophytes suggested by Cook (1996), including plants with photosynthetically active organs that are totally or partially submerged in fresh water or floating in aquatic habitats, either permanently or for several months of the year.

\section{Floristic similarity, life forms, and habitats}

We used geographical coordinates to circumscribe the records in the Amazon part of Mato Grosso with the help of the software Q-GIS (Q-Gis.org 2020), according to the delimitation of Brazilian phytogeographic domains (IBGE 2010), excluding records from other domains in the state (Cerrado and Pantanal). The habit description or the collection habitat was determinant for selecting records, which included only wetlands: riparian forests, lakes, ponds, rivers, streams, palm swamps (veredas), floodable grasslands, marshes, swamps, reservoirs, headwaters, igapós (seasonally flooded forests), and igarapés (small streams or channels). We obtained additional information on phytogeographic domains and growth habits from the Brazilian Flora database (http://floradobrasil.jbrj.gov.br/). The species list followed the classification of families proposed by the Angiosperm Phylogeny Group (APG IV 2016) for angiosperms, Smith et al. (2006) for ferns and lycophytes (pteridophytes), and Goffinet and Buck (2004) for bryophytes.

Classification of the species life forms of the aquatic macrophytes followed Irgang and Gastal (1996), based on the horizontal species zoning in the ecosystem and the water depth: amphibious, species that colonize the interface between aquatic and terrestrial habitats; epiphytes/climbers, plants rooted in organic substrates (emergent and/or floating); emergent, rooted plants with emerging leaves and flowers, occurring in shallow areas and close to the shore; and submerged and floating, species of deep and central zones and water bodies, occurring beneath or on the water surface, respectively. We obtained species life forms from our record collection and specific literature (Costa et al. 2016; Moura-Júnior et al. 2015; Pott and Pott 1997).

We categorized the habitat types as follows: lotic (rivers or streams), lentic (lakes and ponds), and intermediate, i.e., reservoirs or ecosystems with abiotic characteristics similar to lotic or lentic habitats (Thornton 1990; Esteves 2011). We categorized the habitats according to the information in herbarium records. The extinction risk of species was categorized using the IUCN database (International Union for Conservation of Nature, Red List of the Brazilian Flora) (http://cncflora.jbrj.gov.br/portal/pt-br/listavermelha). The categories are: Critically Endangered (CR), Endangered (EN), Vulnerable (VU), Nearly Threatened (NT), Least Concern (LC), and Data Deficient (DD). We obtained other characteristics such as endemism and the phytogeographic domain (Amazon and/or Cerrado) of the species from the Brazilian Flora database (http://floradobrasil.jbrj.gov.br).

To obtain a general picture of the potential taxonomic richness in the region, we performed a rarefaction analysis of species to compare the observed (from the records) and the estimated richness (Jackknife 1 estimator), considering years as samples. We used the function alpha.accum of the bat package (R version 3.6.2, Cardoso et al. 2021). We analyzed the similarity between the southern Amazon aquatic macrophyte flora and those of eight other areas, including sites in other Brazilian phytogeographic domains (Table 1). We performed a cluster analysis (UPGMA) based on a presence/absence matrix, using the Simpson index (Magurran 2004). The analysis was conducted in the platform 
$\mathrm{R}$ using the package recluster, function recluster.cons, and recluster.boot ( $\mathrm{R}$ version 3.6.2, Dapporto et al. 2020). We updated all species names according to the Brazilian Flora database (http://floradobrasil.jbrj.gov.br), through the flora package (R version 3.6.2, Carvalho 2020).

\section{Results}

We cataloged 688 species of aquatic macrophytes ( 1 bryophyte, 29 ferns and lycophytes, and 658 angiosperms) in 299 genera (1 bryophyte, 19 ferns and lycophytes, and 279 angiosperms) and 95 families ( 1 bryophyte, 13 ferns and lycophytes, and 81 angiosperms). Of this total, 508 species (74\%) were classified as aquatic macrophytes according to the Repository of Aquatic Plants of Brazil and the Brazilian Flora database, and 115 species (17\%) were classified based on other surveys in the Amazon domain and other domains in Mato Grosso. For this study, we collected 308 species ( $45 \%$ of the total), of which 66 species (9\%) were new records of aquatic macrophytes (Supplementary material; Fig. 2).

The families with the largest number of species were Poaceae (83 species), Cyperaceae (68), Fabaceae (56), Rubiaceae (41), Melastomataceae (27), and Onagraceae (23). These five families represent $43 \%$ of the entire aquatic species richness in southern Amazonia. However, $29 \%$ of the families have only a single species. The genera with the most species were Cyperus (29 species), Ludwigia (23), Rhynchospora (20), Utricularia (17), Borreria (14), and Eleocharis (14), all belonging to the five richest families, mainly Cyperaceae. Over half (59\%) of the genera were represented by a single species (Supplementary material).

According to the Brazilian Flora database, $12 \%$ (79 species) did not have occurrence records for Mato Grosso and 15\% (100 species) had not been recorded in the Amazon domain (Brazilian Flora database). Of the aquatic macrophytes recorded in this study, $13 \%$ ( 89 species belonging to 35 families) are endemic to Brazil, particularly the families Podostemaceae (11 species) and Fabaceae (9). We found 2 species in the Vulnerable category (Mourera weddeliana Tul. - Podostemaceae and Ipomoea subrevoluta Choisy, Convolvulaceae), 1 in Nearly Threatened (Ottelia brasiliensis (Planch.) Walp., Hydrocharitaceae), 47 in Least Concern, and 6 in Deficient Data (Table 2).

Regarding life forms, we found 399 amphibious species (58\%), 170 emergent (19\%), 14 rooted submerged (2\%), 11 free submerged (1.6\%), 20 rooted floating (2.3\%), 7 free-floating (1\%), and 68 epiphytes/climbers (9.4\%). Considering the habitat of occurrence, the lentic species showed the highest richness, with 549 species, of which 241 were exclusive to lentic habitats; followed by lotic with 401 species (115 exclusive), and intermediate with 106 species (20 exclusives). Fifty-six species occur in all three habitat types.

According to the Brazilian Flora database, only 369 species of this group of plants have been recorded in the state of Mato Grosso. In the Amazon basin (southern Amazonia) in this state, the 330 species recorded is more than in other phytogeographic domains in the state, the Pantanal (254) and Cerrado (269). The same database lists only 453 species of aquatic macrophytes for the entire Brazilian Amazonia (Table 2).

The year-based rarefaction curve of species richness did not reach an asymptote (Fig. 3). Therefore, southern Amazonia may harbor an even larger number of species than we present here. Southern Amazonia showed low floristic similarity to other regions and phytogeographic domains. The highest similarity (60\%) was to northern Brazil (Moura-Júnior et al. 2015) and the Xingu River (Abe et al. 2016) (Fig. 4). Southern Amazonia had low similarity to the flora of Virua National Park and igapó sites in northern and central Amazonia, respectively (Fig. 4).

\section{Discussion}

We found a high number of species of aquatic macrophytes (689) for the southern Amazon region, comparable to extensive inventories in larger areas in southern, northeastern, and northern regions of Brazil. We present new records of aquatic macrophyte species, together with their degree of endemism and occurrence restricted to the region. The Neotropical region is recognized for the high diversity of aquatic macrophytes, with 3457 species (Murphy et al. 2019), and its known richness continues to grow with new studies and records, chiefly in Amazonia and ecotones of vegetation types. The flora of this region shows a high degree of endemism, mainly in the northern part of the Amazon domain (Moura-Júnior et al. 2015; Murphy et al. 2019). The richness of aquatic macrophytes is related to several factors, with area size often noted (Ferreira et al. 2011; Murphy et al. 2003; Moura-Júnior et al. 2015; Moura-Júnior and Cotarelli 2019; Oliveira et al. 2019). Thus, the large area occupied by southern Amazonia (Amazonia of Mato Grosso), with $500,000 \mathrm{~km}^{2}$ and a variety of wetlands containing rivers of the main Amazon basins, favors this high diversity of aquatic macrophytes. The bioclimatic conditions related to the low latitude of southern Amazonia, including the high temperature and humidity, variety of water-bodies, and plant cover lead to the high richness of aquatic macrophytes in this region (Murphy et al. 2019). Many studies have documented the increased richness of plant species in lower-latitude regions (Signor 1990; Cox and Moore 2006).

The high species richness recorded here may also be related to the location of the study area in southern Amazonia, in the Cerrado-Amazonia transition. This transition area tends to accumulate a high and often unique floral diversity (Marimon et al. 2006; Maracahipes-Santos et al. 2015; Marques et al. 2020). The meeting of the two largest biogeographic domains in South America, the Amazon and the Cerrado, provides a wide variety of habitats for the permanent or temporary occurrence of many aquatic macrophytes. Furthermore, the main rivers of southern Amazonia, the Juruena, Xingu, and Teles Pires, formed by the confluence of rivers that arise in the Cerrado, such as the Verde and Ronuro rivers, 
may facilitate the distribution and colonization of species in the transition to the Amazon region. This transition zone harbors a high phylogenetic diversity of plants (Silva-Pereira et al. 2020).

The species richness found here exceeds that reported in similar studies, where the number of species did not exceed 300 ( Pott and Pott 1997 ; Costa et al. 2016; Oliveira and Bove 2016). However, comparison among inventories must consider the criteria for inclusion, coverage area, and collecting effort. Nevertheless, this highest number of species records for northern Brazil (515 species) may be related to the larger extent and higher diversity of the areas sampled and the periods when the surveys were taken (Moura-Júnior et al. 2015). For northeastern and southern Brazil, long-term studies with sampling in widely distributed areas have reported high species richness (637 and 760 species, respectively) (Moura-Júnior and Cotarelli 2019; Oliveira et al. 2019). Most surveys in the Amazon region were done before 2016. However, we found the largest number of records between the years 2012 and 2019, derived from collections in aquatic-macrophyte monitoring programs for hydroelectric power plants (UHEs) in the study area, mainly in the Teles Pires River (UHEs Teles Pires, Colíder, and Sinop). Inclusion of this sampling effort in our study contributed to the increase of 343 species records for Amazonia, 29\% of which are new occurrences for this phytogeographic domain. In addition, our inventory revealed four species (Myriophyllum mattogrossensis Hoehne, Apinagia fluitans P. Royen, Lophogyne aripuanensis (A.S. Tav.) C.T. Philbrick \& C.P. Bove, and Borreria flexuosa E.L. Cabral) that occur only in Mato Grosso, and one, L. aripuanensis, that is exclusive to southern Amazonia.

The increase in species records for the region may also be due to failure to include many amphibious/emergent and epiphyte/climber species in the older lists. Labels from collections and herbarium records in Specieslink and GBIF do not adequately specify or describe the life form and/or habitat, hindering the characterization of species as aquatic macrophytes. We included many terrestrial plants that are tolerant of rapid inundation or running water in the sorting criteria. Correct recording of life forms is a key aspect in the study of aquatic macrophytes. We found many amphibious and emergent species, which results in a pattern similar to those found in other floristic studies of aquatic macrophytes, as mentioned above. The high number of amphibious and emergent species is attributable to habitat types such as riparian forests, where these species are frequent and often abundant in these temporarily flooded areas (Pott et al. 2011). The seasonality of other life forms, such as floating and submerged plants, may prevent them from being recorded in the field, since many appear in wetlands for only a short time; this is reflected in the lower number of species and survey records. Accuracy in determination and description of life forms often requires that studies be conducted for extended periods and over several hydrological cycles (Pivari et al. 2019).

The similarity of the macrophytes of southern Amazonia to the species recorded for northern areas of the Amazon domain was high, especially in the Xingu River region, mainly because of its proximity to the eastern boundary of southern Amazonia. Furthermore, the community of aquatic macrophytes showed differences within the Amazon domain, i.e., between central and southern Amazonia, as supported by the low similarity to inventories in the states of Roraima and Amazonas. This difference may be due to the influence of the Cerrado domain on southern Amazonia, as described for the tree flora of these regions by Morandi et al. (2016b). The low floristic similarity of southern Amazonia to the northern Amazon region (Viruá National Park), the Amazon igapó habitats, and the Araguaia River basin may have been influenced by the fewer species recorded in these situations, which although poorest in terms of species numbers, also possess a unique flora with few species shared with the other areas. Studies with greater temporal and spatial coverage in these areas are needed to explore their potential richness.

The richness of herbaceous aquatic macrophytes was determinant for the similarity between the study sites, particularly regarding families such as Poaceae and Cyperaceae. These families are the richest in wetlands worldwide (Murphy et al. 2019) and are very common in Brazilian wetlands, such as the Pantanal (Pott and Pott 1997) and the Paraná River basin (Murphy et al. 2003; Ferreira et al. 2011). The Lista de Espécies da Flora do Brasil (2020) includes 1653 species of Poaceae. Their efficient vegetative propagation (rhizomes and/or stolons) allows species of Cyperaceae and Poaceae to adapt to temporarily or permanently flooded areas, which explains their occurrence in all the habitats analyzed. The richness of Fabaceae in southern Amazonia coincides with studies of aquatic macrophytes in other Brazilian regions such as the Northeast (Moura-Júnior et al. 2019), North (Moura-Júnior et al. 2015), and South (Oliveira et al. 2019), where it is among the five richest families. Also notable is the relative importance of Onagraceae, which in most studies is not among the richest families despite its wide distribution in Brazil (Wagner et al. 2007). However, in our study it had the fifth highest species richness, with the genus Ludwigia.

The high species diversity in the region emphasizes the importance of conserving wetlands and vegetation types where they grow; many species have restricted habitats, as shown, for example, in the endemism levels. Conservation of the vegetation associated with watercourses is directly related to conservation of water resources, mainly in the Amazon region (Zaiatz et al. 2018; Lopes et al. 2020b). Despite this, over time, wetlands in Brazil have not received the economic, ecological and/ or social value that they deserve. On the contrary, many people favor transforming these areas for agriculture and cattle ranching, or for engineering projects such as hydroelectric power stations and roads (Junk et al. 2020), mainly in the so-called deforestation arc in southern Amazonia (Fearnside 2019). A frequent motive for transformation in the ruderal many aquatic macrophytes, which grow rapidly and can become invasiveand colonize impacted habitats (Barbieri and Carreiro 2017; Demarchi et al. 2018). This reinforces the importance of and need for maintenance and conservation of wetlands.

Floristic studies in wetlands in Brazil have continuously increased in sampling areas and number of species (Pivari et al. 2019). The present findings expand the available information on Amazon areas and habitats, and also increase the knowledge of species of aquatic macrophytes

Page 5/13 
that occur in transitional areas such as southern Amazonia. This new information will help to clarify the classification of these areas, which are often relicts of many communities and populations (Márquez et al. 2020). In summary, we recorded a large number of species, families, and life forms of aquatic macrophytes, with a high diversity, high degree of endemism, and several species with restricted occurrence in southern Amazonia, exceeding expectations and suggesting the desirability of further floristic studies in the region.

\section{Declarations}

Funding This article was financially supported by the Decanato de Pós-Graduação, Universidade de Brasília.

Conflicts of interest/Competing interests The authors declare that there is no conflict of interest regarding the publication of this article.

Ethics approval Not applicable.

Consent to Participate Not applicable.

Consent for Publication Written informed consent for publication was obtained from all participants.

Availability of data and material All data generated or analyzed during this study are included in this article.

Code Availability Not applicable.

Supplementary Material Species of Aquatic Macrophytes of Southern Amazonia

Acknowledgments We thank the CNMT Herbarium for providing logistical support for this study. Our thanks to Decanato de Pós-Graduação, Universidade de Brasília for finance suppror, and to the Brazilian governmental agency CAPES (Coordenação de Aperfeiçoamento de Pessoal e Nível Superior or "Coordination of Personnel Improvement and Higher Education”) for a grant (M. O. Cordova and J. F. Keffer, Finance Code 001).

\section{References}

1. Abe DS, Sidagis-Galli C, Tundisi TM, Tundisi JEM, Blanco FP, Faria CRL, Tundisi JG (2015) Additional List of Species of Aquatic Macrophytes in the Lower Basin of the Xingu River. Braz J Biol 75:70-77. https://doi.org/10.1590/1519-6984.03714bm

2. Barbieri R, Carreiro JG (2017) Ecologia de macrófitas aquáticas em campo inundável na APA da Baixada Maranhense. Boletim do Laboratório de Hidrobiologia. 27: 01-08.

3. Cardoso P, Mammola S, Rigal F, Carvalho JC, Cardoso MP (2021) Package 'BAT'

4. Carvalho G (2020) Package 'Flora'

5. Chambers PA, Lacoul P, Murphy KJ, Thomaz SM (2008) Global diversity of aquatic macrophytes in freshwater. In: Balian EV, Lévêque C, Segers H, Martens K (ed) Freshwater animal diversity assessment, Developments in Hydrobiology, vol 198. Springer, Dordrecht, pp 9-26. https://doi.org/10.1007/978-1-4020-8259-7_2

6. Costa SM, Barbosa TDM, Bittrich V, Amaral MCE do (2016) Floristic Survey of Herbaceous and Subshrubby Aquatic and Palustrine Angiosperms of Viruá National Park, Roraima, Brazil. PhytoKeys 58:21-48. https://doi.org/10.3897/phytokeys.58.5178

7. Cook, C.D.K. 1996. Aquatic plant book. Amsterdam: SPB Academic Publishing. 228 p.

8. Cox CB, Moore PD (2006) Biogeography: an ecological and evolutionary approach, 7th Edition. Syst Biol 55:361-63. https://doi.org/10.1080/10635150500541581

9. Dapporto L, Ramazzotti M, Fattorini S, Talavera G, Dennis RHL (2020) Package 'Recluster'

10. Demarchi LO. Lopes A, Ferreira AB, Piedade MTF (2018) Ecologia e guia de identificação: macrófitas aquáticas do Lago Amazônico Editora INPA, Manaus, AM, Brazil.. 44 p.

11. Esteves FA (2011) Fundamentos de Limnologia. 3rd edn. Interciência, Rio de Janeiro

12. Fearnside PM (2019) Impactos das hidrelétricas na Amazônia e a tomada de decisão. Novos Cad NAEA 22:69-96. https://doi.org/10.5801/ncn.v22i3.7711

13. Ferreira FA, Mormul RP, Thomaz SM, Pott A, Pott VJ (2011) Macrophytes in the upper Paraná river floodplain: checklist and comparison with other large South American wetlands. Rev Biol Trop 59:541-556

14. Filgueiras TS, Nogueira PE, Brochado AL, Guala GF (1994) Caminhamento - um método expedito para levantamentos florísticos qualitativos. Cad Geociênc 12:39-43

15. Fortney RH, Benedict M, Gottgens JF, Walters TL, Leady BS, Rentch J (2004) Aquatic Plant Community Composition and Distribution along an Inundation Gradient at Two Ecologically-Distinct Sites in the Pantanal Region of Brazil. Wetl Ecol Manag 12:575-85.

https://doi.org/10.1007/s11273-005-1763-0

Page 6/13 
16. Goffinet B, Buck W (2004) Systematics of the Bryophyta (Mosses): From molecules to a revised classification (PDF Download Available). Monographs in Systematic Botany from the Missouri Botanical Garden 98:205-239.

https://www.researchgate.net/publication/233986259_Systematics_of_the_Bryophyta_mosses_From_molecules_to_a_revised_classification

17. Hess LL, Melack JM, Novo EMLM, Barbosa CCF, Gastil M (2003) Dual-season mapping of wetland inundation and vegetation for the central Amazon basin. Remote Sens Environ 4:404-28. https://doi.org/10.1016/j.rse.2003.04.001

18. Hubbell SP, He F, Condit R, Borda-de-Água L, Kellner J, Steege HT (2009) How many tree species are there in the Amazon and how many of them will go extinct? PNAS 105:11498-11504. https://doi.org/10.1073/pnas.0801915105

19. IBGE - Instituto Brasileiro de Geografia e Estatística. Censo 2010, Mapa de biomas e vegetação. 2010. Disponivel em: https://www.ibge.gov.br/geociencias/informacoes-ambientais/15842-biomas.html?=\&t=o-que-e

20. Irgang BE, Gastal-Jr. CVS (1996) Macrófitas aquáticas da planície costeira do RS. Porto Alegre, UFRGS: 290p.

21. Ivanauskas NM, Monteiro R, Rodrigues RR (2004) Estrutura de um trecho de floresta Amazônica na bacia do alto rio Xingu. Acta Amaz 34:275-299. https://doi.org/10.1590/S0044-59672004000200015

22. Junk WJ, Piedade MT, Wittmann F, Schöngart J (2020) Várzeas Amazônicas: Desafios para um Manejo Sustentáve. Manaus: Editora INPA.

23. Kunz SH, Ivanauskas NM, Martins SV, Silva E, Stefanello D (2008) Aspectos florísticos e fitossociológicos de um trecho de Floresta Estacional Perenifólia na Fazenda Trairão, Bacia do rio das Pacas, Querência-MT. Acta Amaz 38:245-254. https://doi.org/10.1590/S004459672008000200007

24. Lopes A, Crema LC, Demarchi LO, Ferreira AB, Santiago IN, Ríos-Villamizar EA, Piedade MTF (2020a) Herbáceas aquáticas em igapós de água preta dentro e fora de unidades de conservação no estado do Amazonas. BioBrasil 2:45-62.

https://doi.org/10.37002/biobrasil.v9i2.769

25. Lopes, T.R., L.B. Moura, J.G. Nasimento, L.S. Fraga Junior, C.A. Zolin, S.N. Duarte, M.V. Folegatti, and O.N.A. Santos (2020b) Priority areas for forest restoration aiming at the maintenance of water resources in a basin in the Cerrado/Amazon ecotone, Brazil. J South Am Earth Sci 101:102630. https://doi.org/10.1016/j.jsames.2020.102630

26. Magurran A (2004) Measuring biologcial diversity. Blackwell, Oxford

27. Maltchik L, Rolon AS, Schott P (2007) Effects of hydrological variation on the aquatic plant community in a floodplain palustrine wetland of southern Brazil. Limnol 8:23-28. https://doi.org/10.1007/s10201-006-0192-y

28. Maracahipes Santos L, Lenza E, Santos JO dos, Marimon BS, Eisenlohr PV, Marimon Junior BH, Feldpausch TR (2015) Diversity, floristic composition, and structure of the woody vegetation of the Cerrado in the Cerrado-Amazon transition zone in Mato Grosso, Brazil. Braz $\mathrm{J}$ Bot 38:877-887. https://doi.org/10.1007/s40415-015-0186-2

29. Marimon BS, Lima ES, DuarteTG, Chieregatto LC, Ratter JA (2006) Observations on the vegetation of northeastern Mato Grosso, Brazil. IV. An analysis of the Cerrado-Amazonian forest ecotone. Edinb J Bot 63:323-41. https://doi.org/DOI: 10.1017/S0960428606000576

30. Marques EQ, Marimon-Junior BH, Marimon BS, Matricardi EAT, Mews HA, Colli GR (2020) Redefining the Cerrado-Amazonia transition: implications for conservation. Biodivers Conserv 29:1501-1517. https://doi.org/10.1007/s10531-019-01720-z

31. Medeiros GR, Rodrigues-Filho JL, Matsmura-Tundisi T, Tundisi JEM, Abe DS, Oliveira HA, Degani RM, Blanco FP, Faria CRL, Campanelli L, Soares FS, Sidagis-Galli CV, Teixeira-Silva V, Gatti-Júnior P, Tundisi JG (2015) Occurrence of macrophytes species in the lower basin of the Xingu River. Braz J Biol 75:65-69. https://doi.org/10.1590/1519-6984.03114BM

32. Morandi PS, Marimon-Junior BH, de Oliveira EA, Reis SM, Valadão MBX, Forsthofer M, Passos FB, Marimon BS (2016a) Vegetation succession in the Cerrado-Amazonian forest transition zone of Mato Grosso State, Brazil. Edinb J Bot 73:83-93. https://doi.org/10.1017/S096042861500027X

33. Morandi PS, Marimon BS, Eisenlohr PV, Marimon-Junior BH, Oliveira-Santos C, Feldpausch TR, Oliveira EA, Reis SM, Lloyd J, Phillips OL (2016b) Patterns of tree species composition at watershed-scale in the Amazon 'arc of deforestation': implications for conservation. Environ Conserv 43:317-326. https://doi.org/10.1017/S0376892916000278

34. Moura-Júnior EG, Cotarelli VM (2019) An update on the knowledge of aquatic macrophytes in Northeast Brazil. Rodriguésia 70 : e04452017 https://doi.org/10.1590/2175-7860201970076

35. Moura-Júnior EG, Paiva RMS, Ferreira AC, Pacopahyba LD, Tavares AS, Ferreira FA, Pott A (2015) Updated checklist of aquatic macrophytes from Northern Brazil. Acta Amaz 45:111-32. https://doi.org/10.1590/1809-4392201402662

36. Murphy KJ, Dickinson G, Thomaz SM, Bini LM, Dick K, Greaves K, Kennedy MP, Livingstone S, McFerran H, Milne JM, Oldroyd J, Wingfield RA (2003) Aquatic plant communities and predictors of diversity in a sub-tropical river floodplain: the upper Rio Paraná, Brazil. Aquatic Bot 77:257-276. https://doi.org/https://doi.org/10.1016/S0304-3770(03)00108-6

37. Murphy K, Efremov A, Davidson TA, Molina-Navarro E, Fidanza K, Betiol TCC, Chambers P, Grimaldo JT, Martins SV, Springuel I, Kennedy M, Mormul RP, Dibble E, Hofstra D, Lukács BA, Gebler D, Baastrup-Spohr L, Urrutia-Estrada J (2019) World distribution, diversity and endemism of aquatic macrophytes. Aquatic Bot 158:103127. https://doi.org/10.1016/j.aquabot.2019.06.006

Page $7 / 13$ 
38. Oliveira A, Bove C (2016) Checklist of aquatic and marshy Monocotyledons from the Araguaia River basin, Brazilian Cerrado. Biodivers Data J 4:e7085. https://doi.org/10.3897/BDJ.4.e7085

39. Oliveira LS, Andrade BO, Boldrini II, Moço MCC De (2019) Aquatic vascular plants of South Brazil: checklist and a comparative floristic approach. Acta BotBras 33:709-715. https://doi.org/10.1590/0102-33062019abb0194

40. Oliveira-Filho AT. 2017. NeoTropTree: tree flora of the neotropical region: a database involving biogeography, diversity and conservation. Belo Horizonte, Universidade Federal de Minas Gerais. http://www.neotroptree.info

41. Pivari MOD, Melo PHA de, Souza FS, Stehmann JR, Moura Júnior EG de, Moreira SN, Pott VJ, Pott A, Lopes A, Moço MCC, Oliveira LS, Lins ALA, Arruda R, Morais IL de, Silva GS, Ferreira RM (2019) New initiatives for brazilian aquatic plant data management. Acta Bot Bras 33:7887. https://doi.org/10.1590/0102-33062018abb0280

42. Pott VJ, Pott A, Lima LCP, Moreira SN, Oliveira AKM (2011) Aquatic macrophyte diversity of the Pantanal wetland and upper basin. Braz J Biol 71:255-263. https://doi.org/10.1590/S1519-69842011000200004

43. Pott VJ, Pott A (1997) Checklist das macrófitas aquáticas do Pantanal, Brasil. Acta Bot Bras 11:215-227. https://doi.org/10.1590/S010233061997000200010

44. Schneider B, Cunha ER, Espínola LA, Marchese M, Thomaz SM (2019) The importance of local environmental, hydrogeomorphological and spatial variables for beta diversity of macrophyte assemblages in a Neotropical floodplain. J Veg Sci 30:269-280.

https://doi.org/10.1111/jvs.12707

45. Signor PW (1990) The Geologic History of Diversity. Annu Rev Ecol and Syst 21:509-539. https://doi.org/10.1146/annurev.es.21.110190.002453

46. Silva-Pereira I, Meira-Neto JAA, Rezende VL, Eisenlohr PV (2020) Biogeographic transitions as a source of high biological diversity: Phylogenetic lessons from a comprehensive ecotone of South America. Perspect Plant Ecol Evol Syst 44:125528. https://doi.org/10.1016/j.ppees.2020.125528

47. Smith AR, Pryer KM, Schuettpelz E, Korall P, Schneider H, Wolf PG (2006) A classification for extant ferns. Taxon 55:705-731. https://doi.org/10.2307/25065646

48. Sousa WTZ, Thomaz SM, Murphy KJ (2011) Drivers of aquatic macrophyte community structure in a Neotropical riverine lake. Acta Oecol 37:462-475. https://doi.org/10.1016/j.actao.2011.05.015

49. The Angiosperm Phylogeny Group, Chase MW, Christenhusz MJM, Fay MF, Byng JW, Judd WS, Soltis DE, Mabberley DJ, Sennikov AN, Soltis PS, Stevens PF (2016) An update of the Angiosperm Phylogeny Group classification for the orders and families of flowering plants: APG IV. Bot J Linn Soc 181:1-20. https://doi.org/10.1111/boj.12385

50. Torello-Raventos M, Feldpausch TR, Veenendaal E, Schrodt F, Saiz G, Domingues TF, Djagbletey G, Ford A, Kemp J, Marimon BS, Marimon Junior BH, Lenza E, Ratter JA, Maracahipes L, Sasaki D, Sonké B, Zapfack L, Taedoumg H, Villarroel D, Schwarz M, Quesada CA, Ishida FY, Nardoto GB, Affum-Baffoe K, Arroyo L, Bowman DMJS, Compaore H, Davies K, Diallo A, Fyllas NM, Gilpin M, Hien F, Johnson M, Killeen TJ, Metcalfe D, Miranda HS, Steininger M, Thomson J, Sykora K, Mougin E, Hiernaux P, Bird MI, Grace J, Lewis SL, Phillips OL, Lloyd J (2013) On the delineation of tropical vegetation types with an emphasis on forest/savanna transitions. Plant Ecol Divers 6:101-137. https://doi.org/10.1080/17550874.2012.762812

51. Veloso HP, Rangel Filho AL, Lima JCA (1991) Classificação da vegetação brasileira, adaptada a um sistema universal. IBGE, Rio de Janeiro

52. Wagner, W. L., P. C. Hoch \& P. H. Raven. 2007. Revised classification of the Onagraceae. Syst. Bot. Monogr. 83: 1-240.

53. Wagner, W. L., P. C. Hoch \& P. H. Raven. 2007. Revised classification of the Onagraceae. Syst. Bot. Monogr. 83: 1-240.

54. Wagner WL, Hoch PC, Raven PH (2007) Revised classification of the Onagraceae. Syst. Bot. Monogr. 83:1-240.

55. Yang W, Yan J, Wang Y, Zhang BT, Wang H (2020) Seasonal variation of aquatic macrophytes and its relationship with environmental factors in Baiyangdian Lake, China. Sci Total Environ 708:135112. https://doi.org/10.1016/j.scitotenv.2019.135112

56. Zaiatz APSR, Zolin CA, Vendrusculo LG, Lopes TR, Paulino J (2018) Agricultural land use and cover change in the Cerrado/Amazon ecotone: A case study of the upper Teles Pires River basin. Acta Amaz 48:168-177. https://doi.org/10.1590/1809-4392201701930

\section{Tables}

Table 1 Aquatic macrophytes floristics studies in Amazonia and other regions and Brazilian phytogeographic domains. MT: Mato Grosso state, MS: Mato Grosso do Sul, GO: Goiás, TO: Tocantins, RR: Roraima, PA: Pará, AM: Amazonas 


\begin{tabular}{|c|c|c|c|}
\hline Region (State) & Phytogeographic Domain & Species Number & Reference \\
\hline Northeast (All States) & Caatinga, Atlantic Forest & 637 & Moura-Júnior and Cotarelli (2019) \\
\hline Midwest (MT, MS) & Pantanal & 242 & Pott and Pott (1997) \\
\hline South (All States) & Atlantic Forest, Pampas & 780 & Oliveira et al. (2019) \\
\hline North (All States) & Amazon & 539 & Moura-Júnior et al. (2015) \\
\hline Midwest, Araguaia river (MT, GO) North (TO) & Cerrado & 162 & Oliveira and Bove (2016) \\
\hline North, Virua National Park (RR) & Amazon & 207 & Costa et al. (2016) \\
\hline North, Xingu River (PA) & Amazon & 295 & Abe et al. (2015); Medeiros et al. (2015) \\
\hline North, Igapós (AM) & Amazon & 174 & Lopes et al. (2020a) \\
\hline
\end{tabular}

Table 2 Number of species of aquatic macrophytes recorded in the Brazilian Flora database, per group, for the state of Mato Grosso and Brazilian Amazonia. MT: Mato Grosso and its phytogeographic domains: Ama-MT: Amazonia of Mato Grosso, Cer-MT: Cerrado of Mato Grosso, Pan-MT: Pantanal, and Ama-BR: Brazilian Amazonia, S-Ama: Southern Amazonia

\begin{tabular}{|lllllll|}
\hline & MT & Ama-MT & Cer-MT & Pan-MT & Ama-BR & S-Ama \\
\hline Angiosperms & 353 & 321 & 258 & 245 & 420 & 658 \\
\hline Ferns and Lycophytes & 10 & 6 & 5 & 5 & 16 & 39 \\
\hline Bryophytes & 6 & 4 & 6 & 4 & 7 & 1 \\
\hline Total of species & $\mathbf{3 6 9}$ & $\mathbf{3 3 0}$ & $\mathbf{2 6 9}$ & $\mathbf{2 5 4}$ & $\mathbf{4 5 3}$ & $\mathbf{6 8 9}$ \\
\hline
\end{tabular}

\section{Figures}



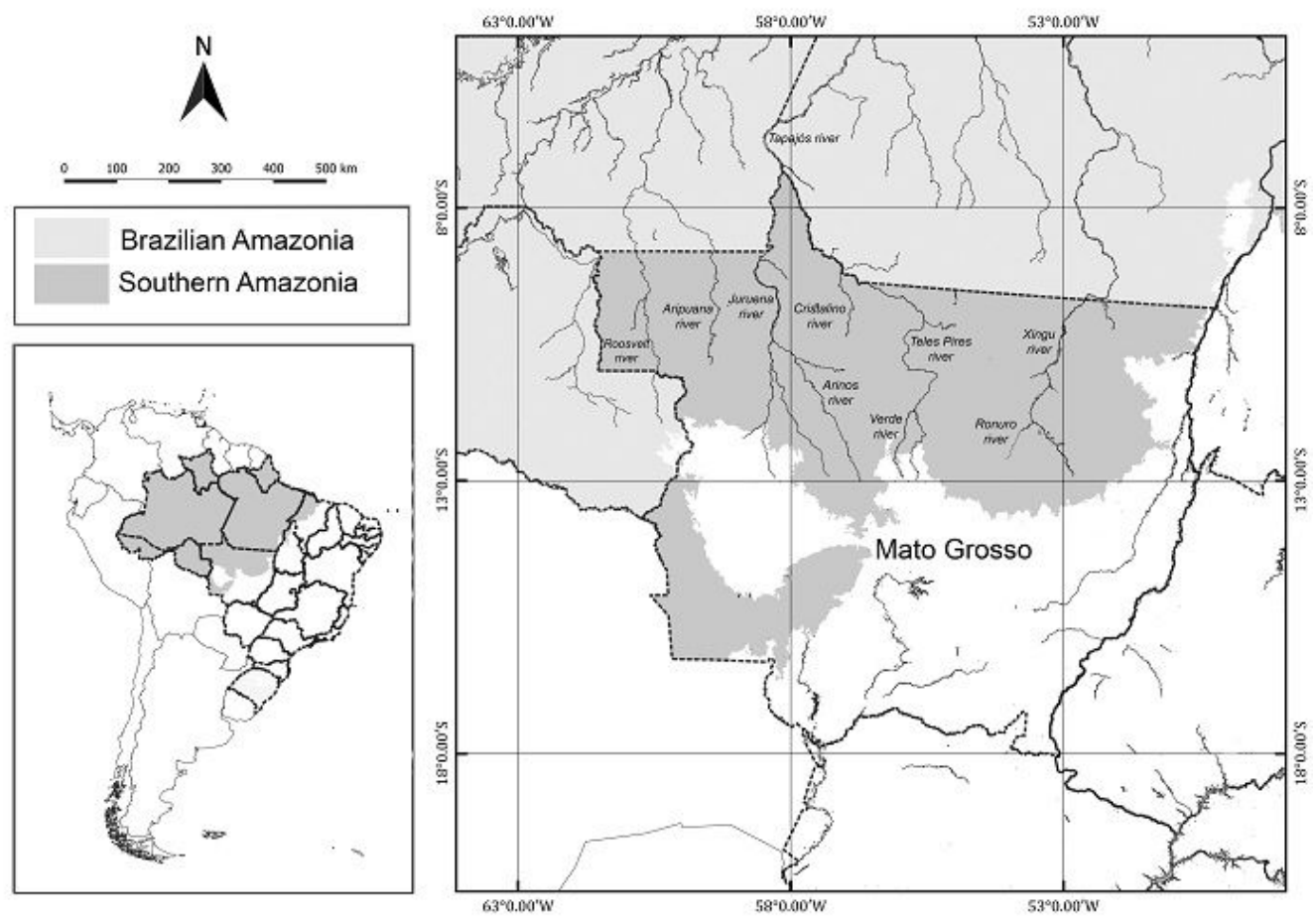

Figure 1

Study area: the part of southern Amazonia located in the mid-northern and eastern areas of the state of Mato Grosso, Brazil Note: The designations employed and the presentation of the material on this map do not imply the expression of any opinion whatsoever on the part of Research Square concerning the legal status of any country, territory, city or area or of its authorities, or concerning the delimitation of its frontiers or boundaries. This map has been provided by the authors. 

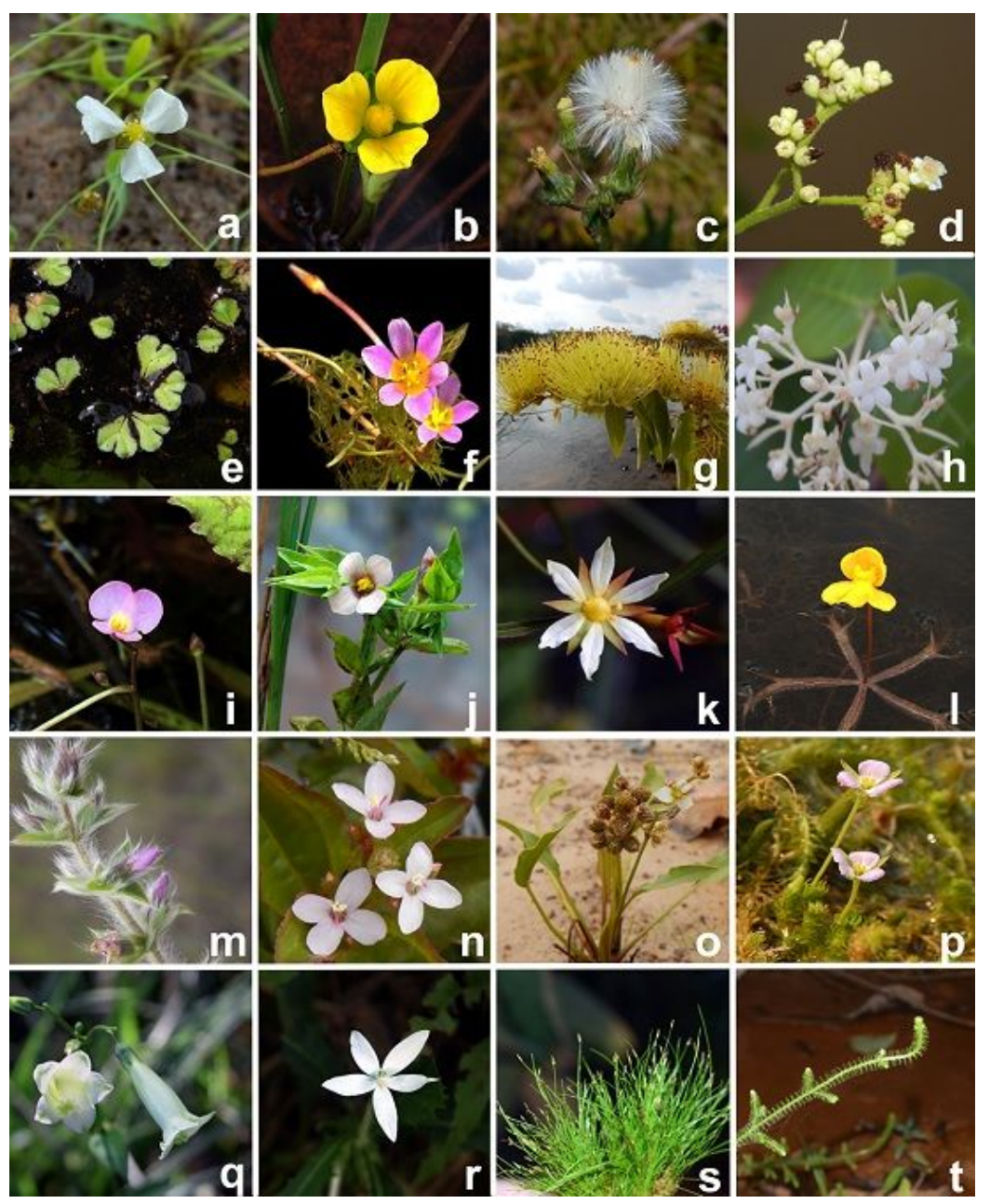

Figure 2

Examples of species of aquatic macrophytes of southern Amazonia. a. Helanthium bolivianum (Rusby) Lehtonen \& Myllys, b. Limnocharis laforesti Duchass. ex Griseb., c. Erechtites hieracifolius (L.) Raf. ex DC., d. Varronia polycephala Lam., e. Ricciocarpos natans (L.) Corda, f. Cabomba furcata Schult. \& Schult.f., g. Combretum lanceolatum Pohl ex Eichler, h. Palicourea amplectens (Benth.) Delprete \& J.H. Kirkbr., i. Utricularia hydrocarpa Vahl., j. Schultesia guianensis (Aubl.) Malme, k. Ludwigia torulosa (Arn.) H. Hara, I. Utricularia breviscapa C. Wright ex Griseb., m. Desmoscelis villosa (Aubl.) Naudin, n. Aciotis acuminifolia (Mart. ex DC.) Triana, o. Echinodorus subalatus (Mart.) Griseb., p. Mayaca sellowiana Kunth, q. Chelonanthus alatus (Aubl.) Pulle, r. Hippobroma longiflora (L.) G. Don., s. Eleocharis minima Kunth, and t. Palhinhaea camporum (B. Øllg. \& P.G. Windisch) Holub. Species in bold are newly recorded as aquatic macrophytes 


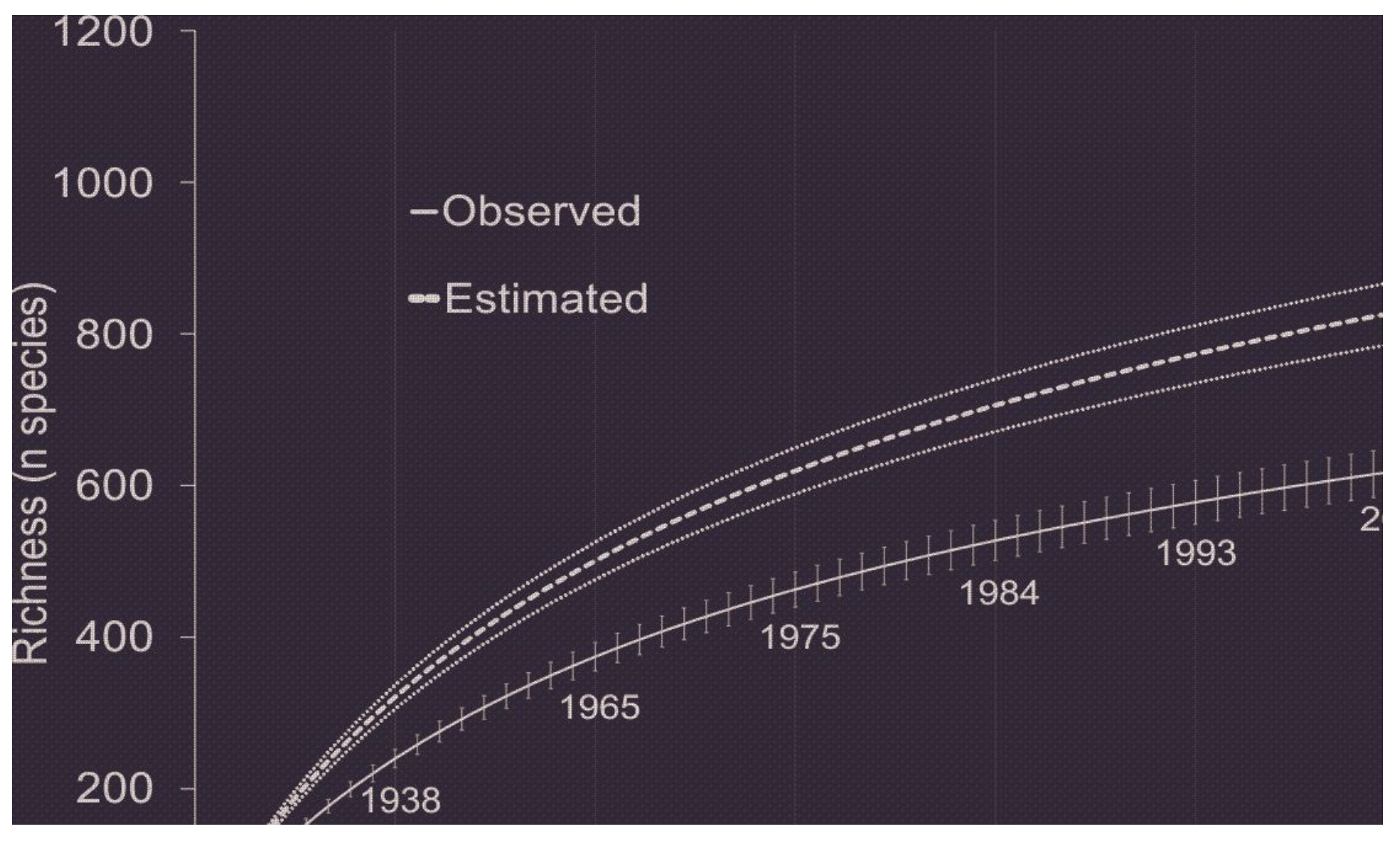

\section{Figure 3}

Year-based rarefaction curve for observed and estimated (Jackknife 1) species richness of aquatic macrophytes in southern Amazonia. Samples represent the species recorded in each year from 1903 to 2020 


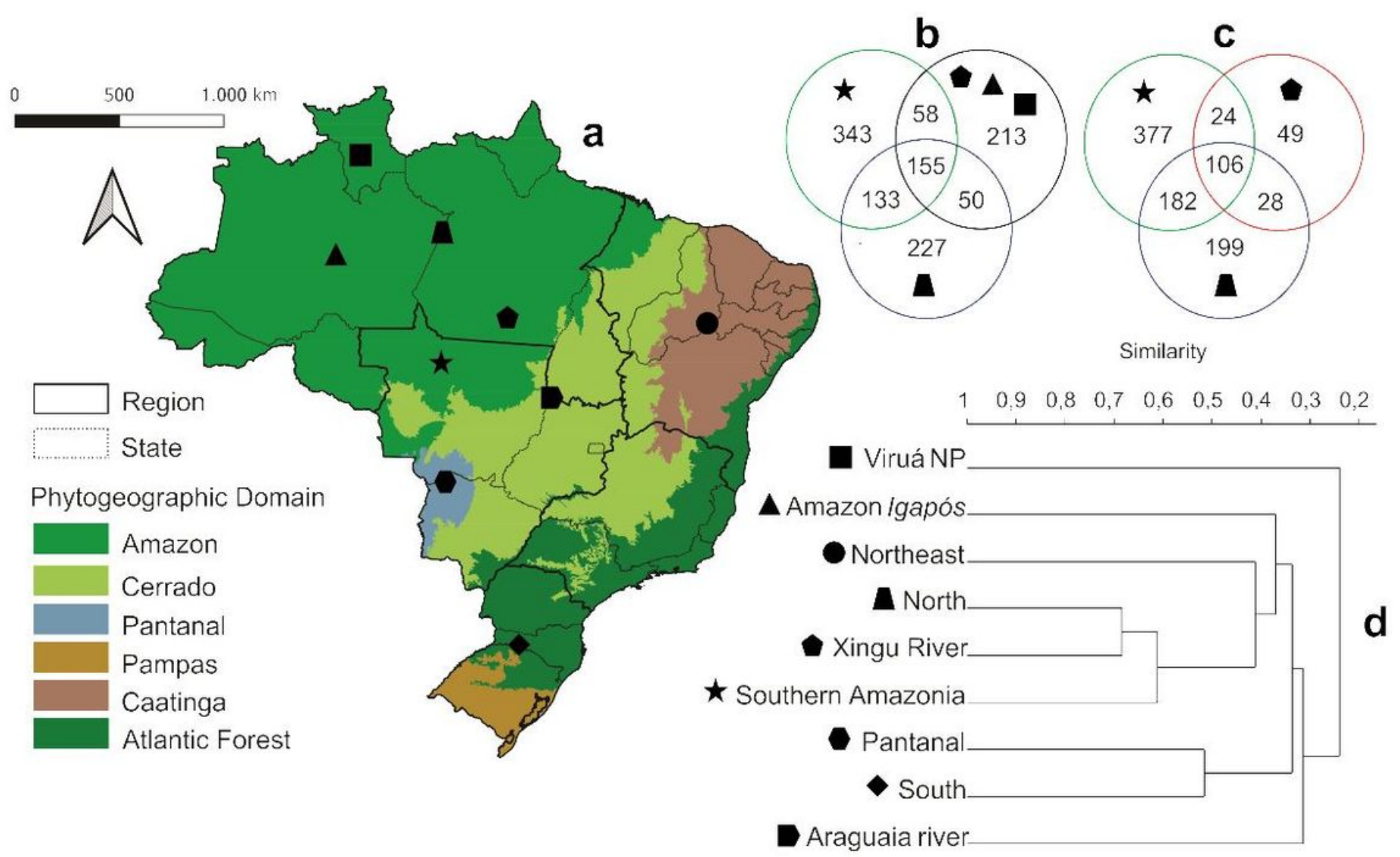

\section{Figure 4}

a. Map showing Brazilian phytogeographic domains and location of the study areas included in the analysis of floristic similarity of aquatic macrophytes. b. Aquatic macrophyte species of southern Amazonia shared with other areas of the Amazon domain. c. Species of southern Amazonia shared with the most similar group in the cluster. d. Cluster analysis dendrogram (UPGMA) based on the Simpson similarity index Note: The designations employed and the presentation of the material on this map do not imply the expression of any opinion whatsoever on the part of Research Square concerning the legal status of any country, territory, city or area or of its authorities, or concerning the delimitation of its frontiers or boundaries. This map has been provided by the authors.

\section{Supplementary Files}

This is a list of supplementary files associated with this preprint. Click to download.

- SupplementarymaterialListofAquaticMacrophytes.docx 